\title{
A New Journal of the American Board of Family Medicine Feature: The American Board of Family Medicine-Robert Graham Center Policy Brief
}

\author{
Larry A. Green, MD (J Am Board Fam Med 2011;24:130-131.)
}

The American Board of Family Medicine (ABFM) is committed to helping improve the care patients receive, particularly from the platform of professional health care delivery in the United States that attends to the needs of the largest proportion of the population each month: the offices of primary care physicians. ${ }^{1}$ The ABFM has embraced Maintenance of Certification (MOC) and its 4 components- focusing on professionalism, practice-relevant learning, proper application of new knowledge, and sustaining a robust medical knowledge base-as one means of improving health care delivery as science and technology evolve. ${ }^{2}$ As of January 1, 2010, the inclusion of all ABFM Diplomates into MOC was completed, and now the ABFM is moving forward with further development of MOC (MOC 2.0) as a set of strategies to improve quality of care that is expected to enhance the health of millions of people.

Now that ABFM is fully devoted to the "quality business," its work and relationships with the American Board of Medical Specialties intersect and interact with national and local policy and innovation work. A complex web of decisions and opportunities muddles toward proper solutions that presently proceed under the code names of patient centered medical home, accountable care organizations, health care reform, Accountable Care Act, personal doctoring, workforce development, "the new epidemiology," evidence-based practice, community engagement, quality measurement and reporting. The urgency for progress toward a sustainable health care system in the United

From the Department of Family Medicine, University of Colorado Denver.

Funding: none.

Conflict of interest: none declared.

Corresponding author: Larry A. Green, MD, Department of Family Medicine, University of Colorado, Mail Stop F496, Academic Office 1, 12631 East 17th Avenue, Room 3521, Aurora, CO 80045-0508 (E-mail: larry.green@ucdenver.edu).
States is exposed, ${ }^{3,4}$ and the need for leadership and action from the profession of medicine is obvious. Because primary care is medicine's proven way of improving care while relieving disparities and containing costs, ${ }^{5}$ the ABFM has both an opportunity and an obligation to respond with what resources it has to contribute to the national aspiration of a transformational change toward a high performance, affordable, and equitable health care system for all.

Among the ABFM's resources are partnerships, knowledge expertise, unique data and information, programs designed to develop professional leaders, a blossoming research enterprise, and scientific publications, specifically the fournal of the American Board of Family Medicine ( $7 A B F M)$. In this issue of $7 A B F M$, the editors initiate a new feature, The ABFM-Robert Graham Center Policy Brief, ${ }^{6}$ a direct result of the ABFM's research partnership with the Robert Graham Center in Washington, D.C.

Policy briefs, by definition, focus on pertinent policy issues and have as distinguishing features brevity, evidence, and a singular focus on movement in a particular direction for a reason. This new $7 A B F M$ feature will provide an outlet for what the $\mathrm{ABFM}$ is learning with its partners and associates, particularly about MOC and its effects and opportunities. This feature is expected, over time, to represent a portfolio of published work that can be cited and used constructively during this next period of the major redesign of US health care. The intended audiences of these $7 A B F M$ briefs are leaders who can make decisions that matter to family medicine and primary care, as well as those individuals subjected to the effects of such decisions, particularly ABFM Diplomates.

The ABFM-Robert Graham Center Policy Briefs will be published after rigorous peer review, consistent with other $\mathcal{F} A B F M$ articles. The $\mathcal{F} A B F M$ and the ABFM Board of Directors will evaluate this 
new feature, and they welcome readers' responses and suggestions for improvement.

\section{References}

1. Green LA, Fryer GE Jr, Yawn BP, Lanier D, Dovey SM. The ecology of medical care revisited. N Eng J Med 2001;344:2021-5.

2. Green LA, Puffer JC. Family medicine at 40 years of age: the journey to transformation continues. J Am Board Fam Med 2010;23(Suppl 1):S1-4.

3. Devoe JE, Dodoo MS, Phillips RL Jr, Green LA. Who will have health insurance in the year 2025? Am Fam Physician 2005;72:1989.
4. Walker D. Comptroller General's forum on health care: unsustainable trends necessitate comprehensive and fundamental reforms to control spending and improve value. Washington, D.C.: US Government Accountability Office; 2004.

5. Starfield B, Shi L, Macinko J. Contribution of primary care to health systems and health. Milbank Q 2005;83:457-502.

6. Bazemore A, Burke M, Xierali I, Petterson S, Rinaldo J, Green LA, Puffer J. Establishing a baseline: health information technology adoption among family medicine diplomates. J Am Board Fam Med 2011;24:132. 